

\section{Kauai, Hawaii: Solar Resource Analysis and High-Penetration PV Potential}

Chris Helm and Kari Burman

Prepared under Task No. IDHW.9170

Technical Report NREL/TP-7A2-47956

April 2010

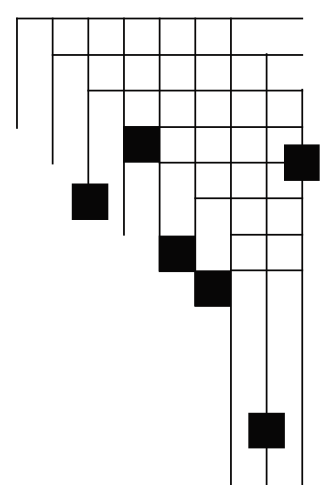




\section{NOTICE}

This report was prepared as an account of work sponsored by an agency of the United States government. Neither the United States government nor any agency thereof, nor any of their employees, makes any warranty, express or implied, or assumes any legal liability or responsibility for the accuracy, completeness, or usefulness of any information, apparatus, product, or process disclosed, or represents that its use would not infringe privately owned rights. Reference herein to any specific commercial product, process, or service by trade name, trademark, manufacturer, or otherwise does not necessarily constitute or imply its endorsement, recommendation, or favoring by the United States government or any agency thereof. The views and opinions of authors expressed herein do not necessarily state or reflect those of the United States government or any agency thereof.

Available electronically at http://www.osti.gov/bridge

Available for a processing fee to U.S. Department of Energy and its contractors, in paper, from:

U.S. Department of Energy

Office of Scientific and Technical Information

P.O. Box 62

Oak Ridge, TN 37831-0062

phone: 865.576 .8401

fax: 865.576 .5728

email: mailto:reports@adonis.osti.gov

Available for sale to the public, in paper, from:

U.S. Department of Commerce

National Technical Information Service

5285 Port Royal Road

Springfield, VA 22161

phone: 800.553.6847

fax: 703.605.6900

email: orders@ntis.fedworld.gov

online ordering: http://www.ntis.gov/ordering.htm 


\section{Executive Summary}

The Hawai' $i$ Clean Energy Initiative (HCEI) is working with a team led by the U.S. Department of Energy's (DOE's) National Renewable Energy Laboratory (NREL) to assess the solar resources available on the island of Kaua' $i$, Hawai' $i$. NREL has coordinated its efforts with the Kauai Island Utility Cooperative (KIUC) to determine the technical feasibility of increasing the contribution of solar renewable energy for electricity generation. NREL developed a custom version of its In My Back Yard (IMBY) software tool specifically for Kaua' $i$ to encourage the implementation of solar energy on Kaua' $i$. The tool is a solar energy calculator that determines how much power can be generated on a specified area of a roof or an open area of land populated with photovoltaics (PV). The custom IMBY-Kaua'i tool uses a Google Maps interface centered on Kaua' $i$ that can zoom in on a given town or open space of land. This tool allows the user to draw a polygon on a roof or open ground area where PV can be installed. Hourly satellite solar radiation information is used to determine the amount of annual solar energy that can be produced from PV for the designated area populated with PV. This IMBY tool was also designed with various features specific to Kaua' $i$, including island financial incentives, residential and commercial load profiles, and agricultural lands desirable for installing PV arrays.

A sample assessment was done using the solar resource and agricultural layers to determine the potential amount of energy that can be produced from ground mount and rooftops available for PV. This analysis evaluated potential PV projects within the agricultural areas designated as desirable for installing PV systems. The analysis also includes rooftops populated with PV. The rooftops selected were primarily large commercial roofs unobstructed by air handling equipment. For this study a separate evaluation was done to analyze the potential power from ground-mount PV generated on the Navy's Pacific Missile Range Facility (PMRF). Other renewable energy assessments are being done by NREL on the PMRF.

It is important to note that we performed this analysis at the macro level, looking at total PV generation across the island (see Table ES-1). This study looks at the technical feasibility of generating power with PV arrays. The study shows that there is potential to generate enough energy to cover the peak load as reported for Kaua' $i$ in 2007 . However, further analysis should be done to determine exact placement of the PV systems and the economic feasibility. 
Table ES-1: PV Energy Potential

\begin{tabular}{lccc}
\hline & Area $\left(\mathrm{m}^{\wedge} 2\right)$ & MW DC & MWh/year \\
\hline $\begin{array}{l}\text { Ground mount inside } \\
\begin{array}{l}\text { D \& E area including } \\
\text { the PMRF }\end{array}\end{array}$ & $10,399,379$ & 830 & $1,239,931$ \\
$\begin{array}{l}\text { Ground mount inside } \\
\text { D \& E area excluding } \\
\text { the PMRF }\end{array}$ & $4,220,575$ & 338 & 491,077 \\
$\begin{array}{l}\text { Rooftop (commercial } \\
\text { only) }\end{array}$ & 136,412 & & \\
\end{tabular}




\section{Table of Contents}

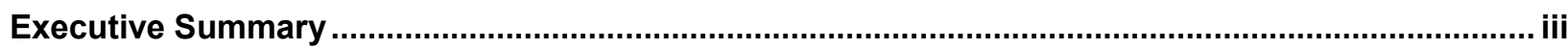

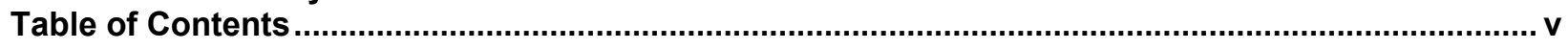

Introduction

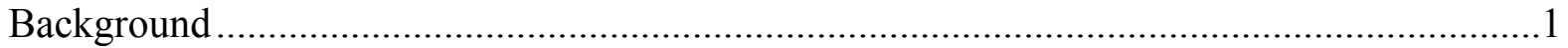

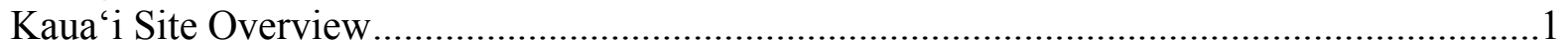

Overview of IMBY Modeling Tool.............................................................................

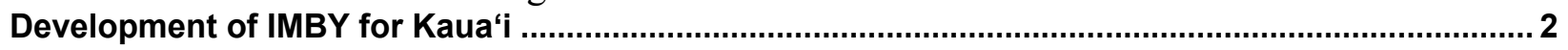

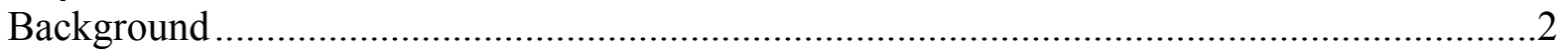

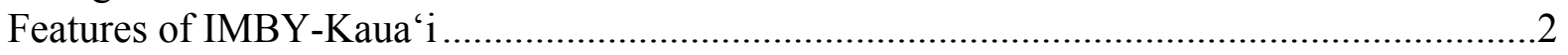

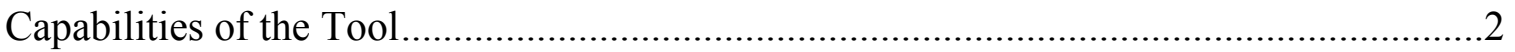

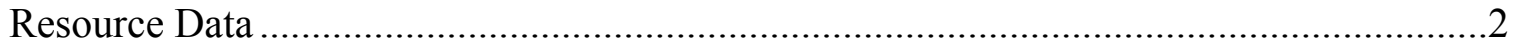

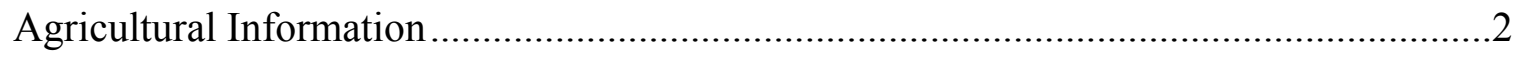

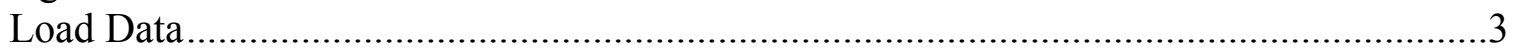

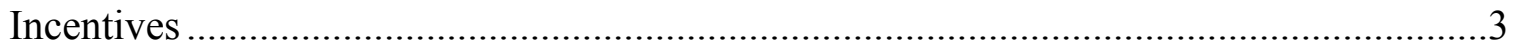

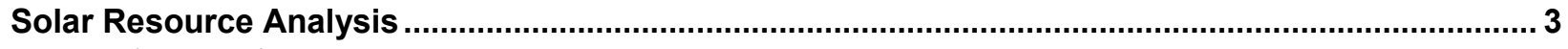

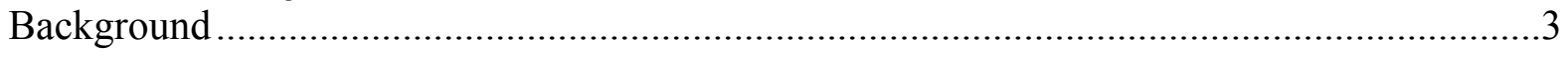

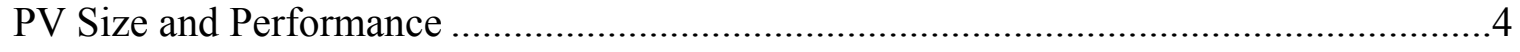

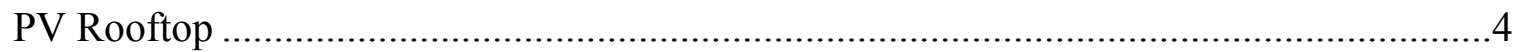

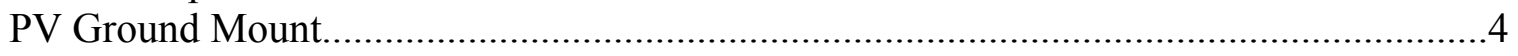

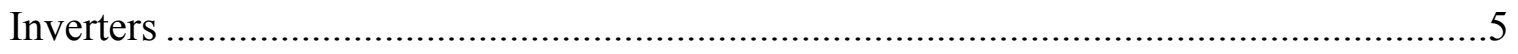

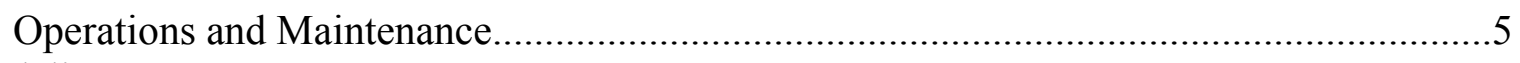

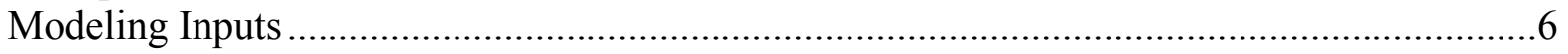

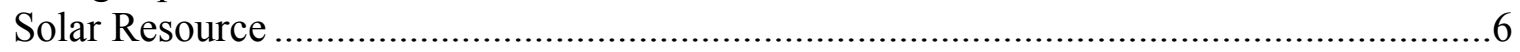

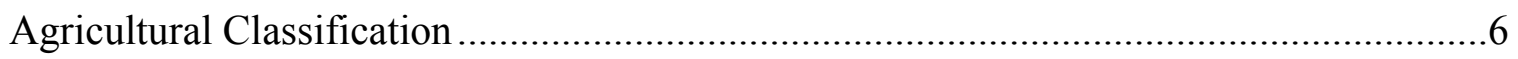

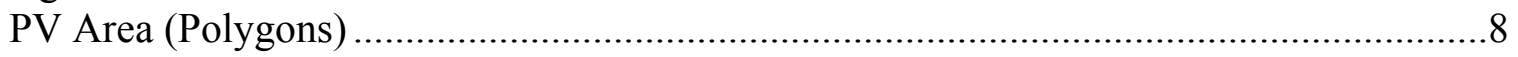

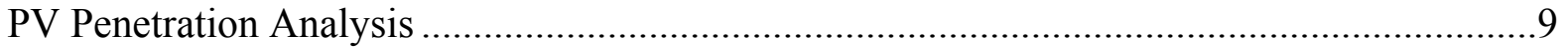

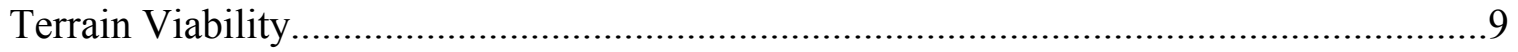

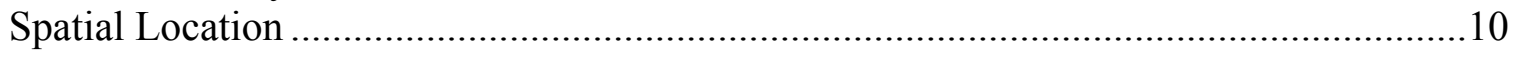

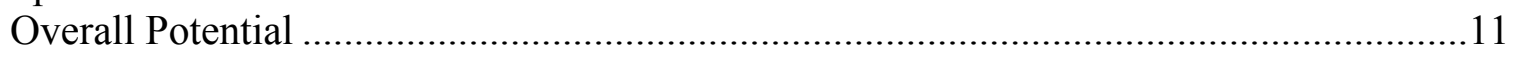

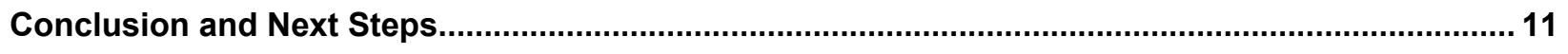




\section{List of Figures}

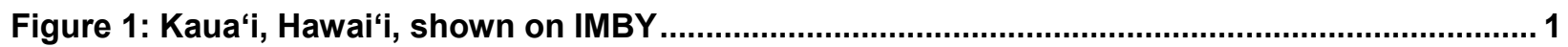

Figure 2: Roof areas on five buildings near Wailua ....................................................................... 4

Figure 3: 1.43-megawatt (MW) PV system on Lana'i, Hawai 'i..................................................... 5

Figure 4: Solar resource on Kaua'i (agricultural lands not shown) ............................................. 6

Figure 5: Kaua'i solar and agricultural Type D \& E intersection ........................................................ 7

Figure 6: Kaua'i, Hawai'i (orange areas are potential sites for PV) .................................................. 7

Figure 7: PV area on the Pacific Missile Range facility............................................................... 8

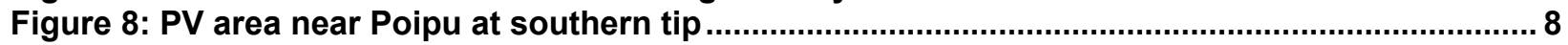

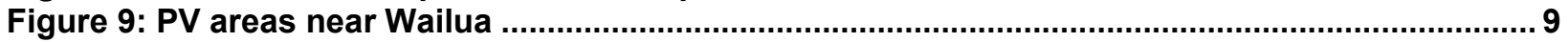

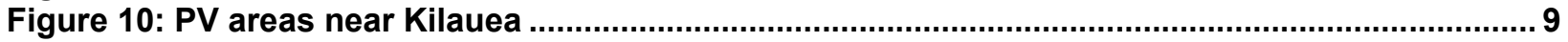

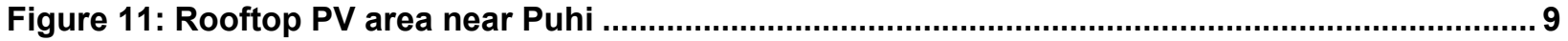

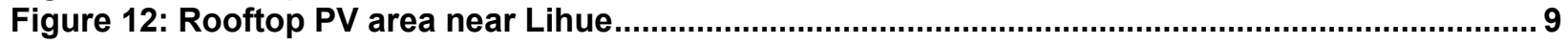

\section{List of Tables}

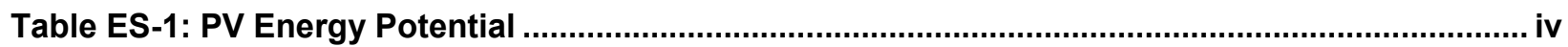

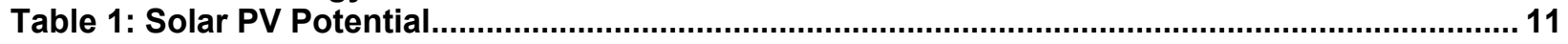




\section{Introduction}

\section{Background}

The National Renewable Energy Laboratory (NREL) partnered with Kauai Island Utility Cooperative (KIUC) in Hawai'i to develop a custom version of NREL's software tool "In My Back Yard" (IMBY) and conduct a detailed solar resource assessment specific for Kaua 'i. As the demand for renewable energy has grown, so too has the need to quantify the potential for these resources. IMBY is a map-based calculation tool that estimates the electricity produced with a solar photovoltaic (PV) array for a given location. This custom IMBY site tool for Kaua' $i$ incorporates solar resource, detailed land classification for agricultural productivity ratings (D \& E). These agricultural ratings (Types D and E) are used to determine areas of low soil productivity and would therefore be candidates for installing ground-mount PV arrays. The solar resource assessment will use this tool to determine the full amount of PV potential on the island.

\section{Kaua'i Site Overview}

Below is the map of Kaua' $i$ that appears on the IMBY tool. The map is displayed in the Hybrid Base Layer mode with solar resource that intersects with the agricultural land Types D and E. The Hybrid Base Layer includes the satellite mode with streets and city names displayed.

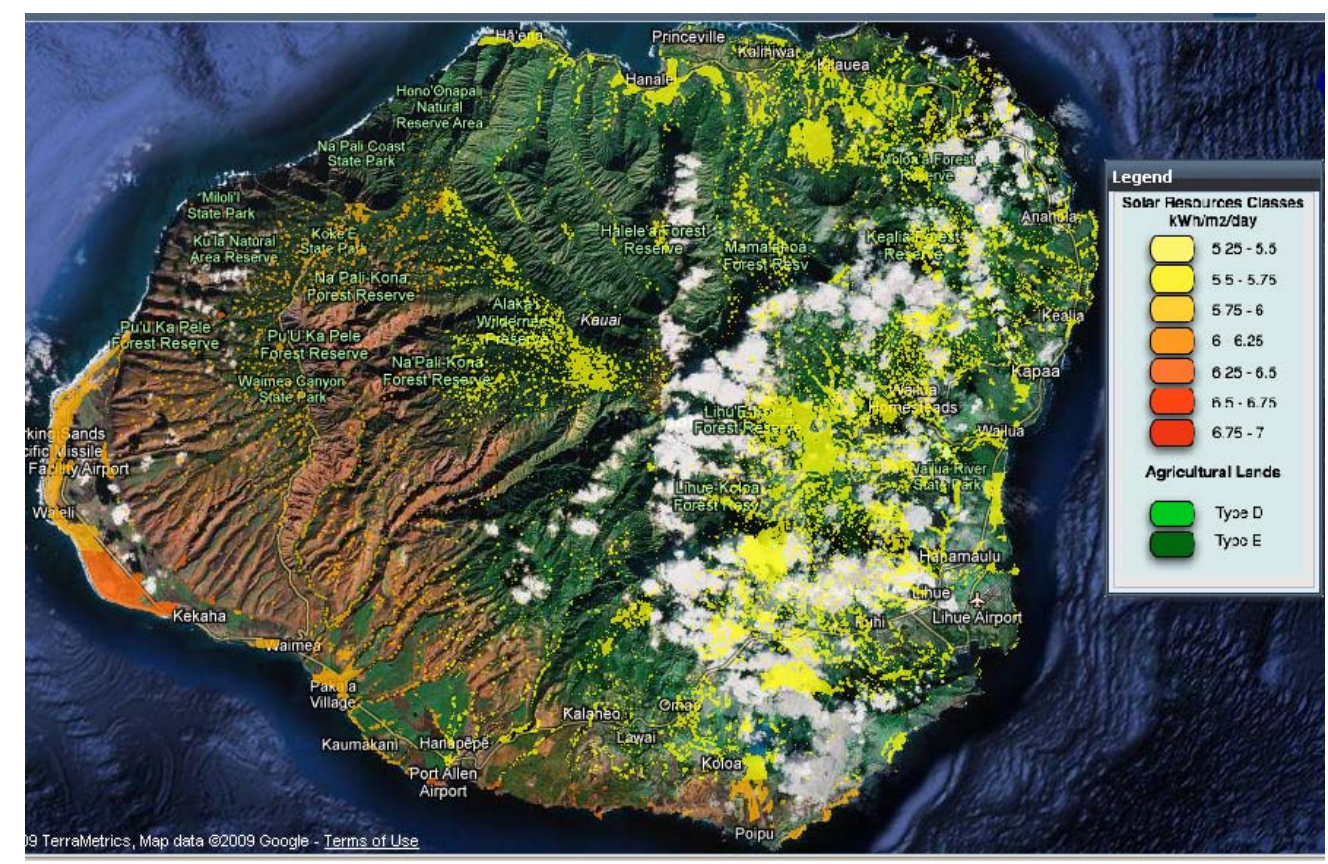

Figure 1: Kaua'i, Hawai'i, shown on IMBY

\section{Overview of IMBY Modeling Tool}

IMBY estimates the size of a polygon drawn by the user on a Google Maps satellite image. Based on this size and an average power density, it then estimates electricity production using the PVWatts performance model, a public tool developed by NREL that estimates energy generation from PV systems based on location-specific resources. IMBY can be used to estimate the size and potential electricity production of any polygon area. The areas can designate a rooftop PV array at an individual home or business or estimate the size of PV arrays over a large area of the island. 


\section{Development of IMBY for Kaua'i}

\section{Background}

This task focused on the development of a custom version of the IMBY tool for the island of Kaua' $i$ and represents the first example of customizing IMBY to a specific location. IMBY was originally developed to run simulations of power generation for any location in the United States; however, this prevented IMBY from incorporating highly localized data regarding utility rates, local incentives, and other types of information that might be useful to users interested in one location. The goals of this work are to 1) create a customized version of IMBY that will showcase the tool's ability to operate in a localized way, and 2) provide the residents of Kaua'i with a functional tool that will help promote the adoption of renewable energy systems on the island.

\section{Features of IMBY-Kaua'i Capabilities of the Tool}

The custom version of IMBY developed for this project does not attempt to deviate drastically from the functionality of the original IMBY tool. Instead, it attempts to increase the usefulness of the tool for a specific location. It does this through the addition of several functionality enhancements that have been requested by the Kauai Island Utility Cooperative (KIUC). These enhancements include adding the capability to 1 ) select a PV system type (either residential or commercial), 2) adjust the electric rate used in the calculation of the simple PV payback, and 3) compare custom (user-supplied) load profiles with the generated PV profiles. These modifications have been made in a way that does not impede the original goal of the IMBY tool and in a manner that is easily replicable for other locations.

\section{Resource Data}

One of the modifications/enhancements made to this version of IMBY is the addition of the solar resource data to the tool's mapping interface. The data added to a site represents the annual daily average solar resource at any given location on the island and has been prefiltered for locations with a slope of $5 \%$ or less. This means that the solar resource data is only displayed for areas with less than a $5 \%$ slope, since land with a steeper slope cannot be utilized for utility-scale development). Users of the tool have the ability to toggle the display of the filtered solar resource data as well as an additional solar resource dataset that has been filtered based on land classification type (discussed below).

\section{Agricultural Information}

The PV site suitability analysis performed in this work requires that a further constraint be placed on the slope-filtered solar resource data. The additional constraint takes into account land use types classified by the State of Hawai'i's Land Study Bureau as Types D and E. Both of these land use types, determined from aerial photography by the Land Study Bureau, represent "acceptable" land on which large-scale PV installations are preferred by the state. To include these land types in this analysis, NREL analysts have removed the solar resource data that does not spatially intersect with land classified as Types D and $\mathrm{E}$. The final solar resource dataset used to determine suitable land for utility-scale PV installation thus represents lands that are flat (less than 5\% slope) and fall within land that has been classified as either Type D or Type E. 


\section{Load Data}

The IMBY software makes use of utility load information to estimate the total impact of a PV installation at a given location. The simulated hourly PV generation estimates are compared with the hourly electric load profiles in order to determine when the PV installation may be reducing the load at the site (i.e., specific day and time). This comparison makes it possible to realistically determine the net-metering and payback period (in years) of the potential PV installation. For this custom IMBY version, residential and commercial load profiles provided by Maui Electric Company (MECO) for the island of Maui were used due to a lack of available data for the island of Kaua 'i. The load data represents only 24 hours of a typical residential and commercial building use in Maui. The one load profile is used throughout the entire year. To increase the accuracy, NREL would like to work with KIUC to develop an annual load profile for the residential and commercial use on the two extreme sides of the island (e.g., near Port Allen and Princeville).

\section{Incentives}

Information about available incentives allows IMBY to estimate the number of years it will take for a consumer to achieve a full payback on the PV installation. IMBY uses federal, state, and local incentives to understand the total initial cost of the PV installation after rebates and tax credits. In the custom Kaua' 1 IMBY version, the database used to determine the incentives is the Database of State Incentives for Renewables and Efficiency (DSIRE). Since Kaua'i does not have a rebate program, the incentives structure already present within IMBY was not modified. However, at KIUC's request, a modification to the payback period calculation was made. This modification made it possible for users to estimate the percentage of their generated electricity that would be supplied back to the grid. This value defaults to $50 \%$, but users who knew they were going to sell only $25 \%$ of their electricity generation, for example, could make that adjustment, and the payback period would reflect their situation more accurately.

\section{Solar Resource Analysis}

\section{Background}

The primary component of a PV system, the PV array, converts sunlight to electrical energy; all other components simply condition or control energy use. Most PV arrays consist of interconnected PV modules that range in size from 50 to 300 peak watts. Peak watts are the rated output of $\mathrm{PV}$ modules at standard operating conditions of $25^{\circ} \mathrm{C}\left(77^{\circ} \mathrm{F}\right)$ and insolation of $1,000 \mathrm{~W} / \mathrm{m}^{2}$. Because these standard operating conditions are nearly ideal, the actual output will generally be less under typical environmental conditions. PV modules are the most reliable components in any PV system. They have been engineered to withstand extreme temperatures, severe winds, and impacts. ASTM E 1038-93 subjects modules to impacts from 1-inch diameter hail at terminal velocity (55 miles per hour) at various parts of the module. PV modules have a life expectancy of 20 to 30 years, and manufacturers typically warranty them against power degradation for 25 years. The array is usually the most expensive component of a PV system; it accounts for approximately two-thirds of the cost of a grid-connected system. There are a large number of PV manufacturers; to ensure the system meets industry standards, it is recommended that the PV system be approved by Go Solar California. 


\section{PV Size and Performance}

The PV arrays must be installed in unshaded locations on the ground or on building roofs that have an expected life of at least 25 years. The predicted array performance was found using PVWatts.

\section{PV Rooftop}

In many cases, the roof is the best location for a PV system. Roof-mounted PV systems are more expensive than ground-mounted systems, but this is a convenient location because it is out of the way and usually unshaded. Large areas with minimal rooftop equipment are preferred, but existing equipment can sometimes be worked around if necessary. If a building has a sloped roof, flush-mounted plates can fit approximately $11 \mathrm{~W} / \mathrm{ft}^{2}$ of capacity. If the building roof is flat, rackmounted, systems can fit approximately $8 \mathrm{~W} / \mathrm{ft}^{2}$ of capacity. For flat roofs, open areas on the south side of any roof, without obstructions, are preferred. Typically, PV panels are only installed on roofs that are less than 5 years old to ensure that the roof's life span is long enough to accommodate the 25- to 30-year life span of the PV system. It is important to note that we used IMBY to perform this analysis at the macro level, looking at total PV generation across the island. The age of the roofs and other details of the potential location should be considered in a more detailed analysis.

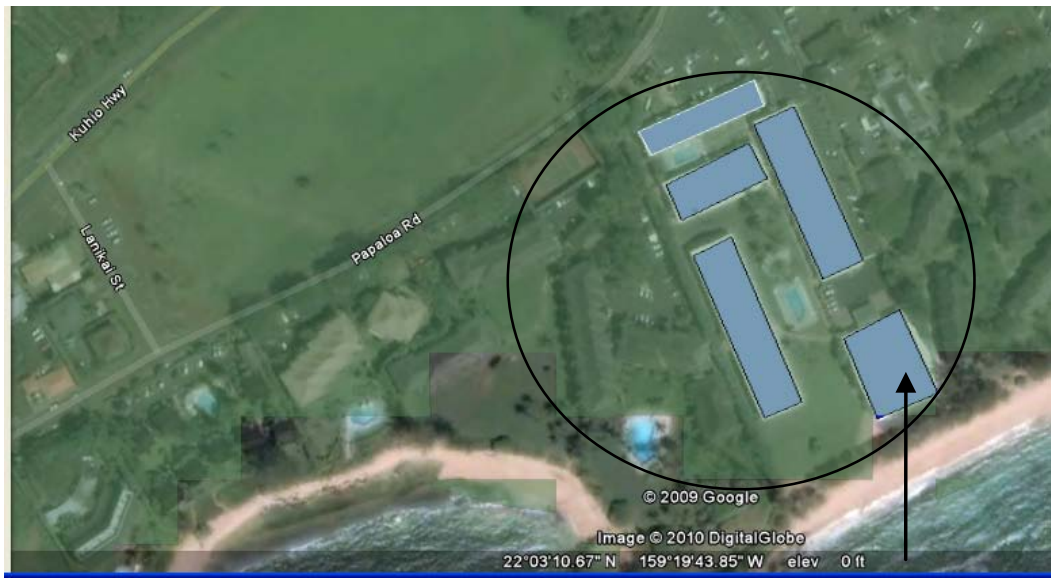

Figure 2: Roof areas on five buildings near Wailua

\section{PV Ground Mount}

Ground-mounted PV systems are the lowest-cost systems. There are several mounting options available, with each having different benefits for different ground conditions. For this analysis, it is assumed that systems are all fixed mount.

To best utilize the ground area available, it is important to consider whether the site layout can be improved to better incorporate a solar system. If there are unused structures, fences, trees, or electrical poles that can be removed, the nonshaded area can be increased to incorporate more PV panels. When considering a ground-mounted system, an electrical tie-in location should be identified to determine where the energy will be fed back into the grid. 


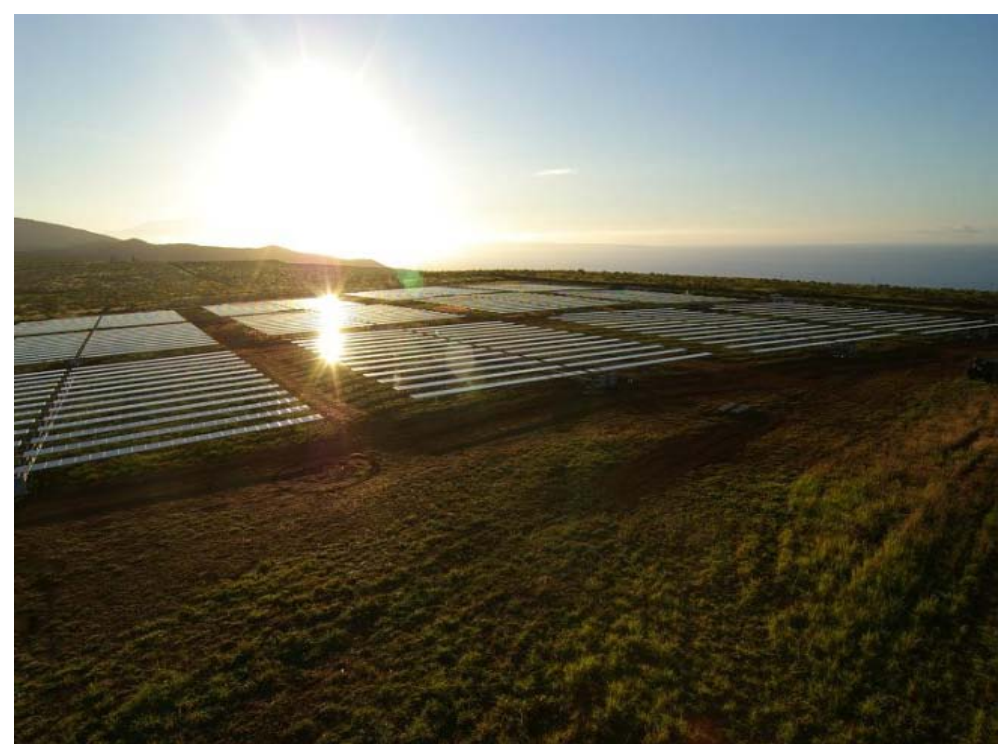

Figure 3: 1.43-megawatt (MW) PV system on Lana'i, Hawai' $i$

\section{Inverters}

PV arrays provide direct current (DC) power at a voltage that depends on the configuration of the array. This power is converted to alternating current (AC) (as used by most common residential, commercial, and industrial equipment) at the required voltage and phase by an inverter. Current inverter technology provides true sine wave power at a quality often better than that of the serving utility. A location for the inverter, along with the balance of the system equipment, should be specified.

Inverters are available that include most or all of the control systems required for operation, including some metering and data-logging capability. Inverters must provide several operational and safety functions for interconnection with the utility system. The Institute of Electrical and Electronic Engineers (IEEE) maintains standard P929, Recommended Practice for Utility Interface of Photovoltaic (PV) Systems, which allows manufacturers to write "Utility-Interactive" on the listing label if an inverter meets the requirements of frequency and voltage limits, power quality, and non-islanding inverter testing. Underwriters Laboratory (UL) maintains standard 1741, The Standard for Inverters, Converters and Controllers for Use in Independent Power Production Systems, which incorporates the testing required by IEEE 929 and includes design (type) testing and production testing.

\section{Operations and Maintenance}

PV modules will typically come with a 25-year performance warranty; the inverters come standard with a 5- or 1-year warranty (extended warranties available) and would be expected to last 10 to 15 years. System performance should be verified on a vendor-provided Web site. The operations and maintenance (O\&M) cost used by IMBY-Kaua' $i$ for PV is $0.6 \%$ of the total kilowatt-hours $(\mathrm{kWh})$ produced over the course of a year. Thus the O\&M cost accounts for \$7.88-\$10.51 per kilowatt $(\mathrm{kW})$ of DC power. ${ }^{1}$

\footnotetext{
${ }^{1}$ Renewable Energy Technology Characterizations, EPRI TR-109496, 1997.C185
} 


\section{Modeling Inputs}

Since IMBY only allows the user to analyze one PV site at a time, the NREL team imported the solar resource file into "My Places" in Google Earth. The file was created for the island of Kaua' $i$ and includes the digital elevation models (DEMs) and topographical data associated with the solar resource and the agricultural layers classified as Types D and E. The intersection of these layers was used to identify multiple areas that could potentially be used for installing ground-mounted PV arrays.

For the purposes of this analysis, the PV modules were tilted to the south at $22^{\circ}$ to match the latitude of Kaua' $i$. The area available for potential power production was assumed to be $80 \%$ of the actual polygon area. This percentage takes into consideration some walk areas both on the roof and between the ground-mounted PV. Cost and incentives were not considered at this time.

\section{Solar Resource}

Below is the solar resource map for Kaua' $i$. The map indicates that Kaua' $i$ has solar resources that vary from a low of $5.25-5.5 \mathrm{kWh} / \mathrm{m}^{2} /$ day to a high resource potential of $6.25-6.50$ $\mathrm{kWh} / \mathrm{m}^{2} /$ day. The areas on the west and southwest side of the island have the highest solar resource potential, while the northeast side of the island has minimal solar resources.

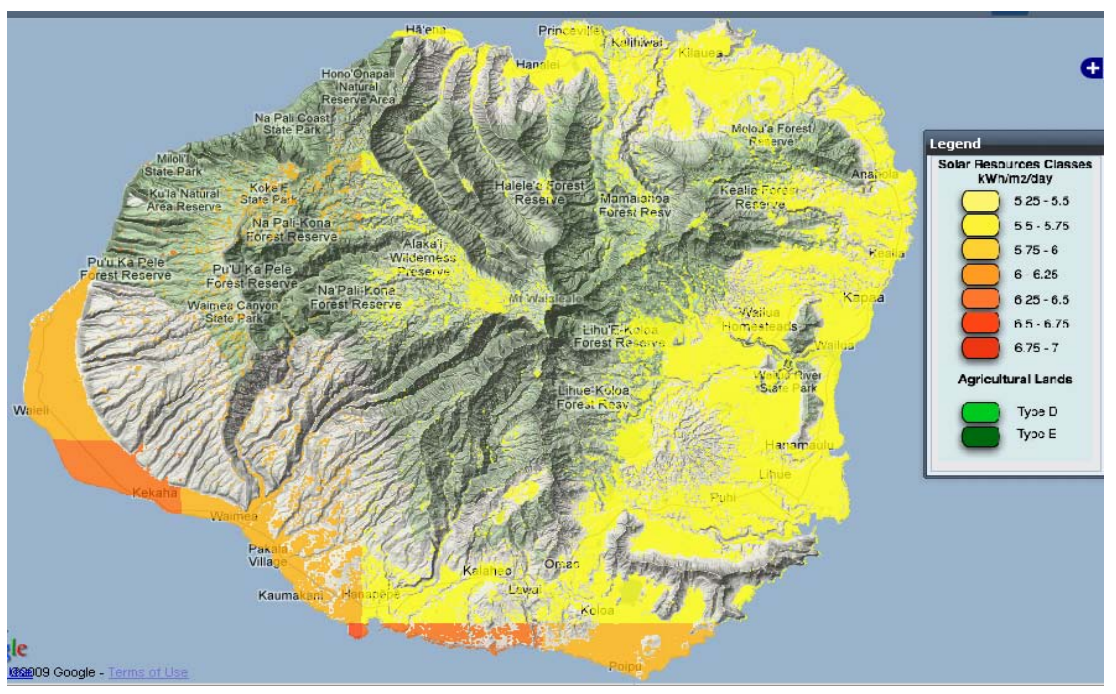

Figure 4: Solar resource on Kaua'i (agricultural lands not shown)

\section{Agricultural Classification}

Land Study Bureau's detailed agricultural land productivity ratings for Kaua' $i$ are referenced in a document on the Hawai' $i$ government GIS Web site ${ }^{2}$. The document defines agricultural productivity ratings from $\mathrm{A}$ to $\mathrm{E}$, with $\mathrm{A}$ having the highest rating. The ratings are based on a study done by the University of Hawaii in the 1970s. The bureau grouped the lands into types that rate the land on its agricultural productivity performance. Types D and $\mathrm{E}$ are relatively poor sites for crop production due to drainage problems with oversaturation of moisture or acidic soil that has high concentrations of calcium. For this study the areas classified as Types D and E were mapped along with the solar resource data, and the intersection of these areas was then used to

\footnotetext{
${ }^{2}$ Land Study Bureau Detailed Land Classification
} 
calculate the potential areas for ground-mounted PV installation. The map below shows the terrain model from the IMBY-Kaua' $i$ tool with the areas highlighted in orange/yellow for the intersection of solar resource and agricultural land Types D and E.

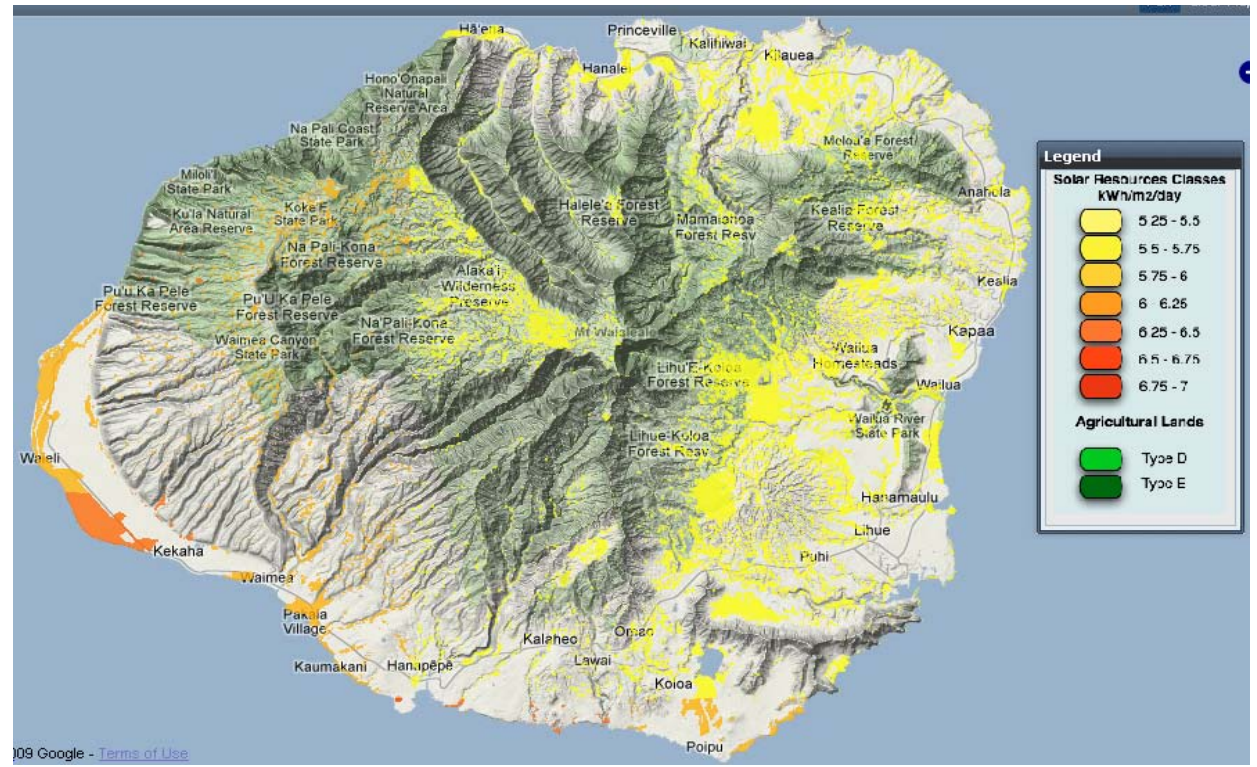

Figure 5: Kaua'i solar and agricultural Type D \& E intersection

The intersection of the agricultural land use and solar resource data was imported into Google Earth, "My Places" to outline the areas where potential ground-mounted PV could be installed. The map below shows the areas in orange that were identified as having high potential for ground-mounted PV and were further analyzed for PV area (see section 3.2.3).

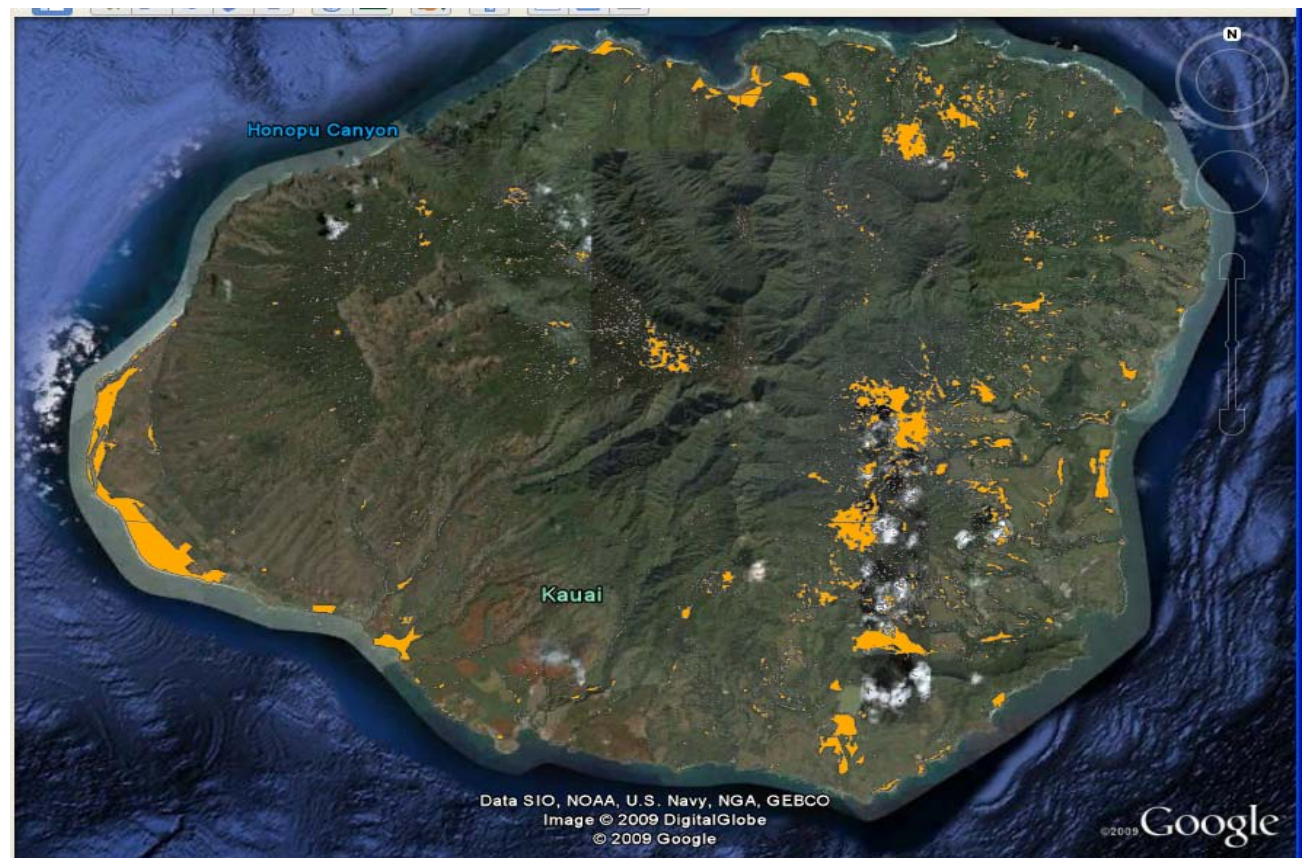

Figure 6: Kaua'i, Hawai'i (orange areas are potential sites for PV) 


\section{PV Area (Polygons)}

The NREL team examined the satellite images to determine the land area composition. Area polygons were drawn to follow roads and avoid homes and buildings. The white outlined polygons represent various areas considered for ground-mounted PV. To avoid the need for new transmission lines, we attempted to use the large tracts of land near towns or resorts.

The availability of roof area was based on visible rooftop obstructions. The satellite image of the buildings was not always clear, so only large building roofs were considered. Roofs were covered to the maximum extent practical, taking into consideration the following factors:

- Rooftop obstructions preventing PV placement

- Shading by rooftop obstructions, parapets, nearby buildings, or trees

- Walkway space required around obstructions and PV panels for access and safety

- Roof aspect—east-, south- and west-facing roofs were covered; north-facing roofs were avoided.

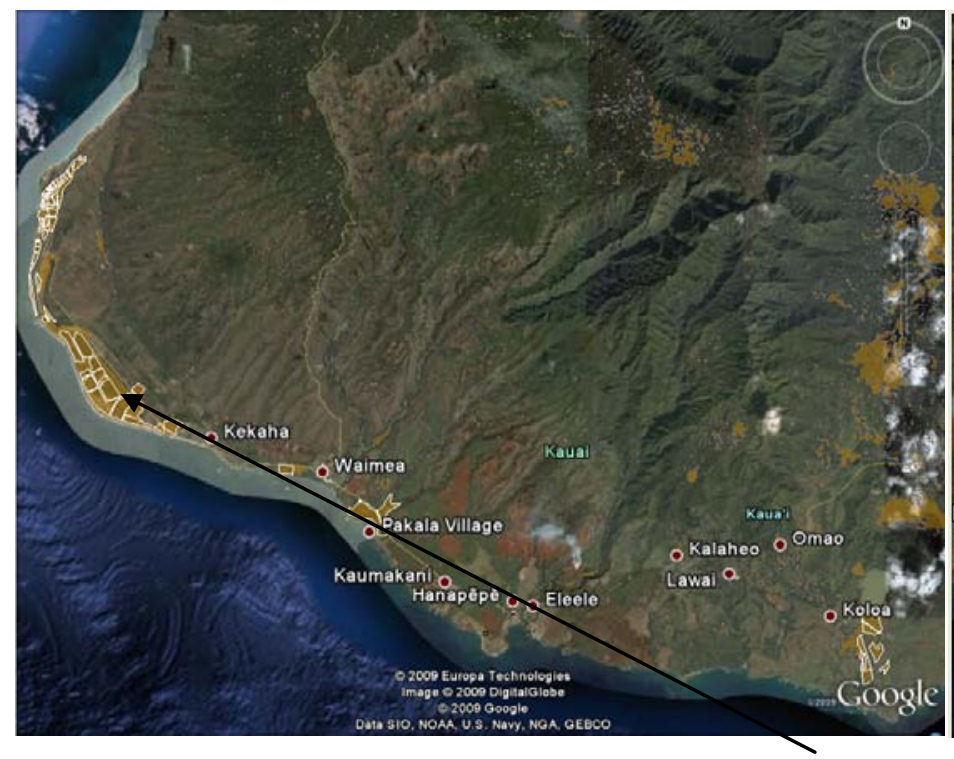

Figure 7: PV area on the Pacific Missile Range facility

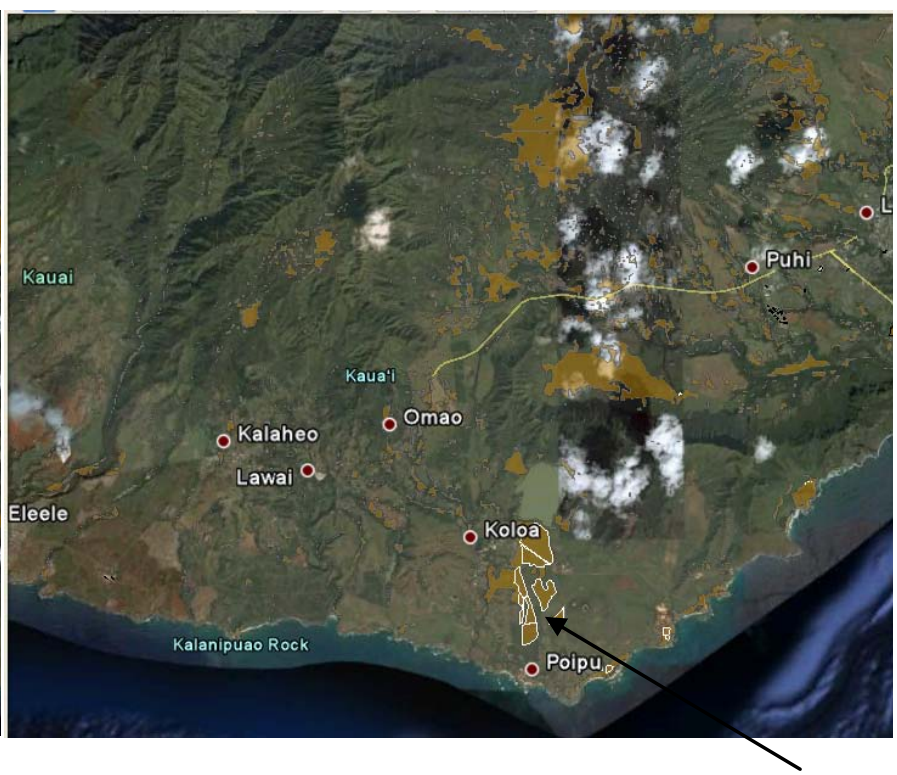

Figure 8: PV area near Poipu at southern tip 


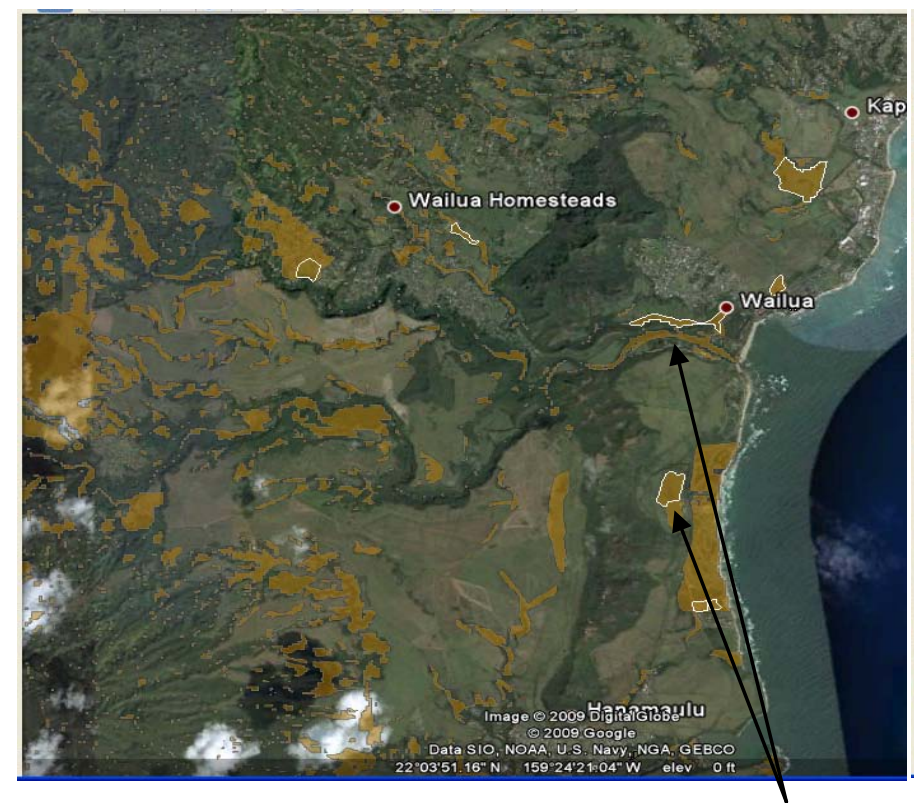

Figure 9: PV areas near Wailua

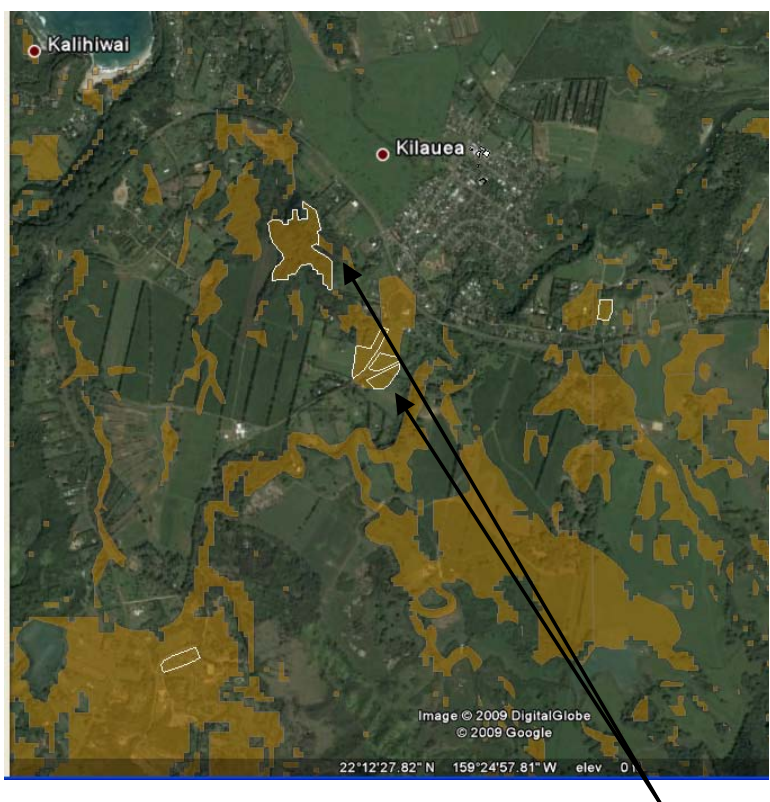

Figure 10: PV areas near Kilauea

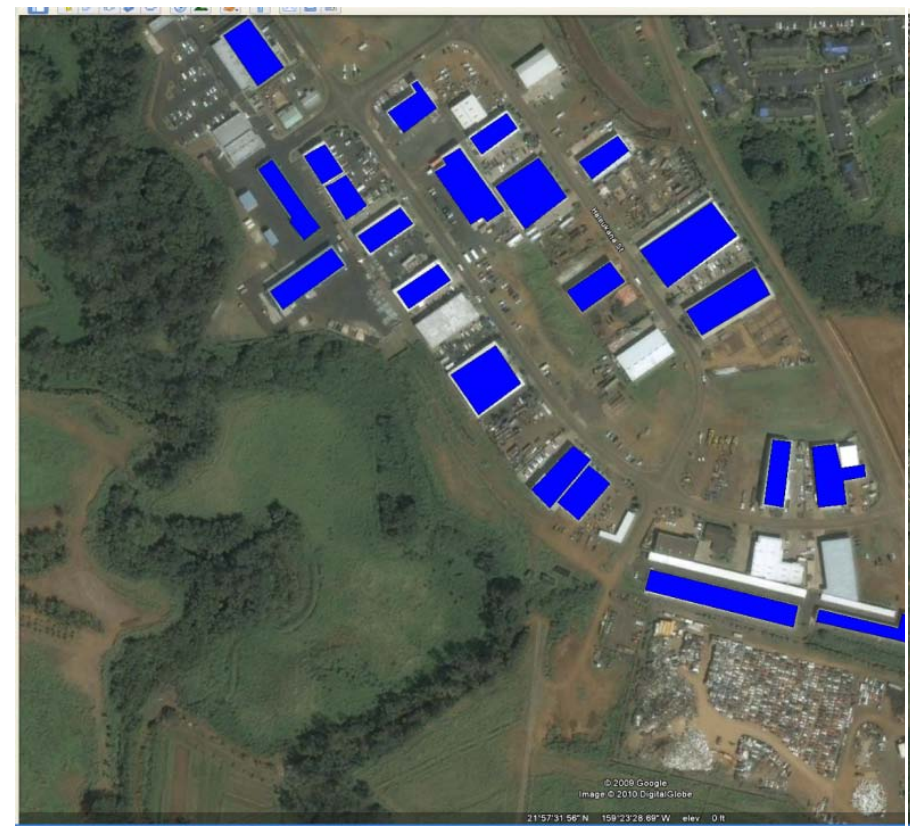

Figure 11: Rooftop PV area near Puhi

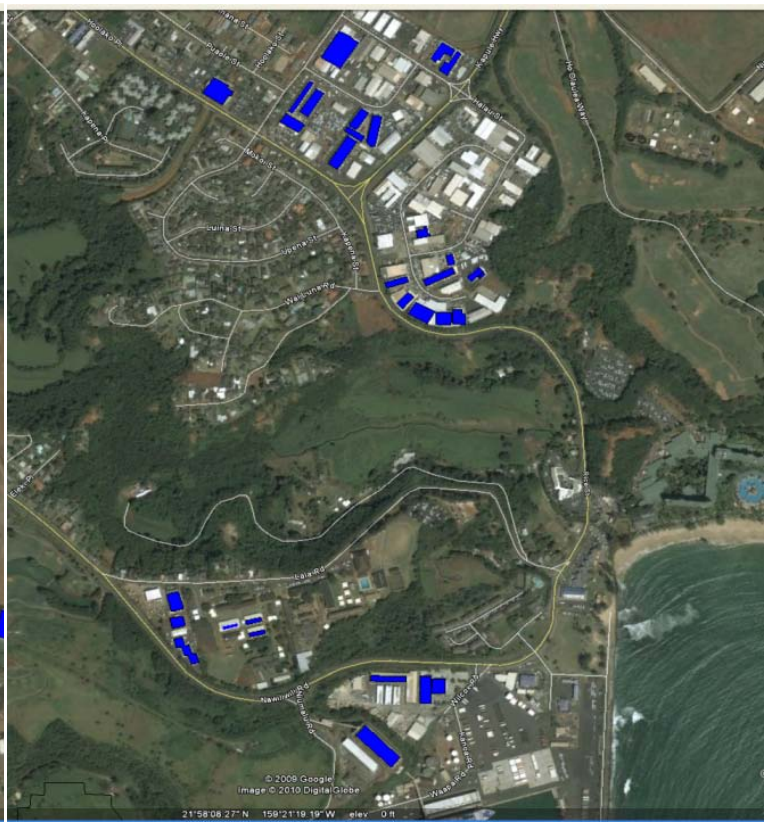

Figure 12: Rooftop PV area near Lihue

\section{PV Penetration Analysis Terrain Viability}

This study primarily analyzed the terrain within the agricultural land Types D and E and intersected with solar resource potential. Kaua' $i$ is very hilly, and some steep terrain was filtered out of the analysis. The solar resource data filtered out any area that has slope greater than $5 \%$. 
KIUC asked that NREL look at land outside the D \& E agricultural land for potential; however, more guidance regarding what land is available for PV is needed for this type of analysis. Therefore, such analysis is therefore not included in this report. Landfill or old mining sites that are no longer used could be considered as some of the first sites to install ground-mount PV arrays if the land is near a transmission line or populated area.

\section{Spatial Location}

Some of the highest potential for PV power generation is on the U.S. Navy's Pacific Missile Range Facility (PMRF) on the west side of the island. Though initially PV installation sites were analyzed on this facility, they were separated out for the overall potential analysis. Other assessments that analyze renewable energy possibilities at this facility are being done for the U.S. Department of Defense.

Note: KIUC administers a 50-kW net-metering policy, which has implications for the size and arrangement of renewable energy systems at PMRF. 


\section{Overall Potential}

The overall potential for PV power production is listed in Table 1 below:

Table 1: Solar PV Potential

\begin{tabular}{lccc}
\hline & Area $\left(\mathrm{m}^{\wedge} 2\right)$ & MW DC & MWh/year \\
\hline $\begin{array}{l}\text { Ground mount inside } \\
\text { D \& E area including } \\
\text { the PMRF }\end{array}$ & $10,399,379$ & 830 & $1,239,931$ \\
& & & \\
$\begin{array}{l}\text { Ground mount inside } \\
\begin{array}{l}\text { D \& E area excluding } \\
\text { the PMRF }\end{array}\end{array}$ & $4,220,575$ & 338 & 491,077 \\
$\begin{array}{l}\text { Rooftop (commercial } \\
\text { only) }\end{array}$ & 136,412 & 11 & \\
\hline
\end{tabular}

\section{Conclusion and Next Steps}

NREL staff, working with KIUC, created an IMBY tool specifically for Kaua'i. The tool is designed to help Kaua' $i$ residents and KIUC determine potential areas to place PV arrays. The IMBY tool is specially designed with the solar resource for Kaua' $i$, along with agricultural areas and incentives specific to the island. The solar resource data is only displayed in areas where the terrain has a slope less than $5 \%$. This is important for utility-scale ground-mount systems.

NREL staff also conducted a study to determine the full amount of PV potential on the island. Areas were mapped on open space within the agricultural D \& E land near communities and on top of large commercial buildings. The analysis indicated that the potential to generate electrical power, even without the prime area on the Navy facility, is extensive and considerably higher than the peak demand of 77.5 MW in 2007. Further analysis needs to be done to determine exact sites available for PV systems and the impact that the distributed generation will have on the electrical infrastructure. 


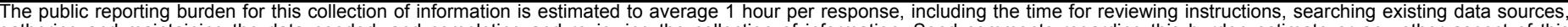

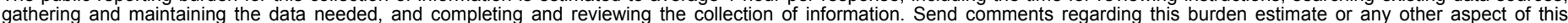

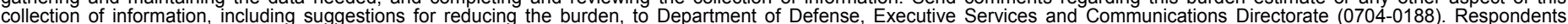

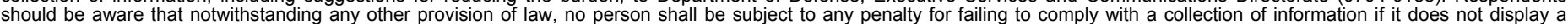

should be aware that notwithstanding

PLEASE DO NOT RETURN YOUR FORM TO THE ABOVE ORGANIZATION.

\begin{tabular}{l|l|l|l} 
1. REPORT DATE (DD-MM-YYYY) & 2. REPORT TYPE & 3. DATES COVERED (FrOm - TO)
\end{tabular}

April 2010

Technical Report

4. TITLE AND SUBTITLE

Kauai, Hawaii: Solar Resource Analysis and High-Penetration PV

Potential

5a. CONTRACT NUMBER

DE-AC36-08-GO28308

5b. GRANT NUMBER

5c. PROGRAM ELEMENT NUMBER

6. AUTHOR(S)

C. Helm and K. Burman

5d. PROJECT NUMBER

NREL/TP-7A2-47956

5e. TASK NUMBER

IDHW.9170

5f. WORK UNIT NUMBER

7. PERFORMING ORGANIZATION NAME(S) AND ADDRESS(ES)

National Renewable Energy Laboratory

1617 Cole Blvd. REPORT NUMBER

Golden, CO 80401-3393

NREL/TP-7A2-47956

9. SPONSORING/MONITORING AGENCY NAME(S) AND ADDRESS(ES)

10. SPONSOR/MONITOR'S ACRONYM(S)

NREL

11. SPONSORING/MONITORING AGENCY REPORT NUMBER

12. DISTRIBUTION AVAILABILITY STATEMENT

National Technical Information Service

U.S. Department of Commerce

5285 Port Royal Road

Springfield, VA 22161

13. SUPPLEMENTARY NOTES

14. ABSTRACT (Maximum 200 Words)

Overview of the solar resource assessment conducted by the National Renewable Energy Laboratory (NREL) in cooperation with Kauai Island Utility Cooperative (KIUC) in Hawai'i to determine the technical feasibility of increasing the contribution of solar renewable energy generation on the island of Kauai'i through the use of photovoltaic (PV) arrays. The analysis, which was performed using a custom version of NREL's In My Back Yard (IMBY) software tool, showed that there is potential to generate enough energy to cover the peak load as reported for Kaua'i in 2007.

15. SUBJECT TERMS

Kauai; Hawaii; Solar Resource; Photovoltaic; PV; High-Penetration PV Potential; Solar Resource Analysis

\begin{tabular}{|c|c|c|}
\hline \multicolumn{3}{|c|}{ 16. SECURITY CLASSIFICATION OF: } \\
\hline $\begin{array}{l}\text { a. REPORT } \\
\text { Unclassified }\end{array}$ & $\begin{array}{l}\text { b. ABSTRACT } \\
\text { Unclassified }\end{array}$ & $\begin{array}{l}\text { c. THIS PAGE } \\
\text { Unclassified }\end{array}$ \\
\hline
\end{tabular}

\begin{tabular}{l|l} 
17. LIMITATION & 18. \\
OF ABSTRACT & OF PAGES \\
UL &
\end{tabular}

19a. NAME OF RESPONSIBLE PERSON

19b. TELEPHONE NUMBER (Include area code) 